\title{
Work Family Conflict of Women Managers in Dhaka
}

\author{
M Sayeed Alam \\ Assistant Professor \\ East West University, Dhaka-1212, Bangladesh \\ E-mail:sbl.dhk@gmail.com \\ Abdus Sattar, Phd \\ Professor \\ East West University, Dhaka-1212, Bangladesh \\ E-mail: asattar@ewubd.edu \\ S.I Nusrat A Chaudhury \\ Associate professor \\ East West University, Dhaka-1212, Bangladesh
}

Received: August 15, 2010 Accepted: March 10, 2011 doi:10.5539/ass.v7n7p108

\begin{abstract}
This research paper investigates the work-family conflict (WFC) of women managers in Dhaka. Through stratified sampling four strata are selected (Doctors, Teachers, Bankers and Managers) and then total forty samples are chosen from different strata. From this study it is revealed that longer working hours affect work family balance directly and children are the worst victims of this WFC. This study confines itself within Dhaka metropolis. The scope of this study can be further extrapolated through bigger sample size and wider study area.
\end{abstract}

Keywords: Work family conflict, Working hours, Dhaka, Children, Women manager

\section{Introduction}

The Work-family is a major problem for working mothers (e.g Aryee et al, 1999, Ng et al, 2002). The cohesion between work and family is important for many people (Whitely and England, 1977), and, unsurprisingly, the research on work-family conflict (WFC) has become a major area in organizational research (Parasuraman and Greenhaus, 2002).

Work-family conflict is defined as "a form of inter-role conflict in which the role pressures from the work and family domains are mutually incompatible in some respect" (Greenhaus and Beutell, 1985, p. 77). There are two types of work-family conflicts (Boyar et al, 2008)

A. "work interfering with family" (WIF); and

B. "family interfering with work" conflict (FIW) (e.g. Carlson et al., 2000; Frone et al., 1992a, 1996; Gutek et al., 1991; Netemeyer et al., 1996).

Work-family conflict and family-work conflict are distinctive, but are conceptually related forms of inter-role conflict (Frone et al., 1992; Netemeyer et al., 1996). Work-family conflict refers to "a form of inter-role conflict in which the general demands of, time devoted to, and strain created by the job interfere with performing family-related responsibilities" and family-work conflict refers to "a form of inter-role conflict in which the general demands of, time devoted to, and strain created by the family interfere with performing work-related responsibilities" (Netemeyer et al., 1996, p. 401).

Both forms of conflict basically result from an individual's attempts to meet an overabundance of demands emanating from the home/family and work domains in which the individual operates (Boles et al., 2001). The demands coming from one domain make performance of roles in the other domains more difficult. Yavas et al 
(2008) contend that there are three possible consequences of work-family and family-work conflicts: emotional exhaustion, poor job performance and higher turnover intentions.

This study targets married female professionals working in Dhaka city and examines their work-family conflict experiences. Western literature broaches upon this topic (e.g. Ferber and O'Farrell, 1991; Hochschild, 1997; Pleck, 1977), but information is rarely available for research on work family conflict in Bangladesh. The unique socio-economic fabric of Dhaka make this study an interesting one to have a deeper look into the relational dynamics between husband-wife, children-mother, and professional women- domestic help.

\section{Background of Work Family Conflict (WFC)}

Researchers agree that increases in demand and supply are some of the salient features of "work interfering with family" The work-family literature has traditionally assumed that variables associated with the family domain (e.g. childcare, household work) predict Family to Work Conflict (FWC), and that from work domain variables (e.g. hours worked weekly, job autonomy) predict Work to family conflict (WFC) (Beauregard, 2006).

Longer working hour have been shown to make a positive impact on WFC (Fu and Shaffer, 2001). It is plain and common to see that the more time spent in the work domain inevitably results in less time available at home, rendering the mountain of responsibilities associated with family roles more difficult.(Beauregard, 2006).

Meeting the expectations of superiors and putting on consistent performances on a regular basis and working for more than regular working hours have also been shown to contribute to WFC (Major et al., 2002).

Work role stressors such as overload and personal-professional conflicts are known to create boredom in the work domain that spills over into the family domain (Fu and Shaffer, 2001). This process appears to operate straightforwardly into one direction; however, it has been suggested that exposure to stress and mechanical works may increase the level of stress. (Ursano et al., 1996), and it is therefore, possible that increased strain on one domain (e.g. work) would reflect on another domain (e.g. FWC). Research by Hughes et al. (1992) supports this proposition by trying to find out how work pressures and work-related insecurities force employees into prioritizing professional matters over the family issues.

Parental demands also affect work-family conflict. Parents tend to experience more work-family conflicts than non-parents as they need to spend greater amount of time at home taking care of their children and shouldering the responsibilities of their families. Parental demand is measured by the number of children and their age. Younger children spend more time with their families. But the professional job holders fail to shoulder the responsibility of family and professional life with equal measure. Problems arise more in case of large families. (Greenhaus and Beutell, 1985).

Past research studies have shown that increased parental workload results in higher work-family conflict. Pleck et al. (1980) reported that parents experience more work-family conflict than married couples without children.

The supportive behavior of family members can help to safeguard work-family conflict experienced by working women. The support can be congenial, emotional or instrumental (Kim and Ling 2001). A pro-feminist sex-role attitude from spouses can reduce work-family conflict for the working wives (Greenhaus and Beutell, 1985). Emotional support refers to the display of sympathetic and caring behavior such as taking interest in the spouse's work, willingness to listen, and giving suggestion and advice when they are needed (Kim and Ling 2001). Instrumental support is the actual assistance to help in task accomplishment, which includes helping out in household chores and childcare. Instrumental support can mitigate time pressure and parental demand that causes work-family conflict (King et al., 1995).

\section{Methodology}

\subsection{Focus of the study}

This study attempts to have a first degree exploration on the WFC scenario in the context of Dhaka .

\subsection{Research Method}

Data were obtained through structured questionnaire. A structured questionnaire was used to collect information from 100 working managers, out of which, 44 were collected, 40 were completely filled up with an yield of $40 \%$ rate of response. Authors have used probabilistic stratified sampling method. The 4 specific strata for this research are: teachers, doctors, bankers and managers. The target population of this study was married women managers in Dhaka city. A manager is one who has the authority to delegate and who has few (at least subordinates) to supervise. 


\section{Research Findings}

4.1 Findings from the survey

a. Demographic Profile (Table -1 at the appendix)

i. Years in Service: Mean value is 2.95; i.e most of the respondents are in service for 5 to less than 10 years.

ii. Most of the respondents are either graduate or masters degree holders, the mean value is 1.65

iii. Age of the respondents is within $40 \mathrm{yr}$.

iv. Average daily working hours is more than 7 to less than 10 hours

v. Maximum number of children is 2

vi. In most of the cases, for household support the respondents depend on maid or parents in law.

b. Working hours: The study reveal that work hour is the major variable which affects work -family equilibrium. Pleck et al, 1980 also said that excessive work time has long been seen as the major culprit affecting work-family balance. From figure 1 , it is seen that $52 \%$ of the respondents agree that working hour plays a significant role towards WFC where as 33\% of them have an opposite view. The individual responses are shown in figure 2.

c. Responsibilities towards children: 77.5 percent of the respondents had children (47.5 percent had one and 30 percent had two children). 80 percent of the respondents agree that children are the worst sufferers of the WFC (Table -III). To balance work and family role was especially severe while the children were sick. Children wanted to spend more time with their mother. The average mother said that because of this WFC they felt guilty. The experiences of three working mothers were as follows. Individual respondent answer to this statement is shown in figure 3. Following verbatims show the intensity of WFC:

One mother said that her parents-in-law looked after her son while she was at work. Her son is now established and settled abroad. During his grooming period, being a mother, she never heard any complaint from her son. She was happy and felt that despite a working mother she performed her motherly role efficiently with the help from the family. A few years back she revealed that her son complained to one of his cousins that he was growing up in his mother's negligence.

Another mother expressed that her boy was under supervision of the maid servant while she was at work. Before leaving for the office she gave sufficient food to the maid so that her son gets the right amount of nutrition. A few years later the working mother discovered that her boy was fed half the milk and the rest of the milk was taken by the maid. The mother was in tears while disclosing this truth to the researchers.

Another mother shared that hers son was at sleep when she left home at the early morning. After waking up from the sleep the baby looked for his mother and when he could not find the mother he started (the child) crying and stopped taking any food. The mother phoned very frequently from her office, talked to her son and let him understand. But listening to the voice of mother child became more agitated. He was only two years old.

Most of the respondents (64.51, percent) said that their children were looked after by maid while they were at work. 19.35 percent revealed that their parents-in-law looked after their children during their stay at work. The respondents said that when the maids looked after the children the following problems occur:

1. Physical torture by the maid is most common. Children were threatened not to say anything negative to their mothers. This torture is most detrimental.

2. Insufficient care taken by the maids.

Mothers said that during adolescence, girls expect more attachment with their mother.

d. Social responsibility: Working women encounter schedule conflict because of their greater family responsibility (Pleck et al, 1980). The role of a homemaker requires them to perform various tasks such as cooking, housework and shopping. Studies have shown that working women with non-standard work schedules have more time for housework (Pleck and Staines, 1984; Spain and Bianchi, 1996). 
87.5 percent of the respondents said that their household jobs were supported by maids. Unlike childcare, household chores are easy tasks to delegate without any detrimental effect. Still working mothers felt lots of pressure from the in laws family regarding different social issues. Respondent said that because of the social responsibilities they failed to enjoy the vacation also. They said that they do not have any personal time at home after returning from the job. Family and social responsibilities made the home into another version of office and they had to solve all the problems before going to bed for sleep.

One respondent said that she had to stay with her parents in law. After returning home she had to address different family and social issues raised by her mother in law, or sister in law. She said that after joining work for the last two years it seemed to her that she was working round the clock and she failed to watch any movie as she failed to manage any time.

\section{Conclusions}

Findings from the research indicate that work-family conflict has become a significant problem for the married professional women in Dhaka city. Married working women at Dhaka are guilty of demands playing multiple roles as a mother and professional. Not only they have to look after their children but also have to take care of their responsibilities at home and run after other errands and attend social and cultural functions. They appear to get little or no support from their husbands and colleagues. There are no specific coping strategies that are followed by the married professionals. In order for empowerment and solvency, women are opting for work in national, multinational and educational institutions. In so doing, they are taking multiple responsibilities by keeping both home and outside happy with their hardworking dedication and passion.

Women's role is vital in family and office. Work family conflict impedes them from doing justice to their talent and it also hampers them from leading a blissful life.

Some researches are conducted in the organizational level to identify the attitude of managers towards women managers. The research area is new for Dhaka's context but situation of Work to family conflict (WFC) has grown severe in recent times. The scenario could be represented simply through a verbatim, "you know about glass "glass house". You (MEN) can see the sky. Everybody says sky should be your limit. For us, we see the sky through a barrier. I want to break it.!!”.

\section{References}

Aryee, S. (1992). Antecedents and outcomes of work-family conflict among married professional women: evidence from Singapore. Human Relations, Vol. 45, No. 2, pp. 813-37.

Aryee, S., Luk, V., Leung, A. and Lo, S. (1999). Role stressors, inter-role conflict, and well-being: the moderating influence of spousal support and coping behaviors among employed parents in Hong Kong. Journal of Vocational Behavior, Vol. 54, pp. 259-78.

Beauregard Alexandra T. (2006). Are Organizations Shooting themselves in the foot? Work place contribution to family- to -work conflict. Equal Opportunities International, Vol. 25, No. 5, pp 336-353.

Boles, J.S., Howard, W.G. and Donofrio, H.H. (2001). An investigation into the inter-relationships of work-family conflict, family-work conflict and work satisfaction. Journal of Managerial Issues, Vol. 13, No. 3, pp. 376-90.

Boyar L. Scott, Maertz P Carl Jr, Mosley C. Donald Jr and Carr C. Jon. (2008). The Impact of Work/family demand on work family conflict. Journal of Mechanical Psychology, Vol. 23, No. 3, pp 215-235.

Carlson, D.S. and Kacmar, K.M. (2000). Work-family conflict in the organization: do life role values make a difference?. Journal of Management, Vol. 26, pp. 1031-54.

Ferber, M.A. and O'Farrell, B. (1991). Work and Family: Policies for a Changing Workforce. National Academy Press, Washington, DC.

Frone, M.R., Russell, M. and Barnes, G.M. (1996). Work-family conflict, gender, and health-related outcomes: a study of employed parents in two community samples. Journal of Occupational Health Psychology, Vol. 1, pp. 57-69.

Frone, M.R., Russell, M. and Cooper, M.L. (1992). Antecedents and outcomes of work-family conflict: testing a model of the work-family interface. Journal of Applied Psychology, Vol. 77, No. 1, pp. 65-78.

Frone, M.R., Yardley, J.K. and Markel, K.S. (1997). Developing and testing an integrative model of the work-family interface. Journal of Vocational Behavior, Vol. 50, No. 2, pp. 145-67. 
$\mathrm{Fu}$, C.K. and Shaffer, M.A. (2001). The tug of work and family: direct and indirect domain-specific determinants of WFC. Personnel Review, Vol. 30, No. 5, pp. 502-22.

Greenhaus, J.H. and Beutell, N.J. (1985). Sources of conflict between work and family roles. Academy of Management Review, Vol. 10, No. 1, pp. 76-88.

Gutek, B.A., Searle, S. and Klepa, L. (1991). Rational versus gender role explanations for work-family conflict. Journal of Applied Psychology, Vol. 76, pp. 560-8.

Hochschild, A.R. (1997). The Time Bind: When Work Becomes Home and Home Becomes Work. Metropolitan Books, New York, NY.

Kim Siew Lee Fean and Ling Seow Choo. (2001). Work-Family conflict of women entrepreneurs in Singapore. Women in Management review, Vol. 16, No. 5, pp-204-221.

King, L.A., Mattimore, L.K., King, D.W. and Adams, G.A. (1995). Family support inventory for workers: a new measures of perceived social support from family members. Journal of Organizational Behavior, Vol. 16, pp. 235-58.

Major, V.S., Klein, K.J. and Ehrhart, M.G. (2002). Work time, work interference with family, and psychological distress.Journal of Applied Psychology, Vol. 87, No. 3, pp. 427-36.

Netemeyer, R.G., Boles, J.S. and McMurrian, R. (1996). Development and validation of work-family conflict and family-work conflict scales. Journal of Applied Psychology, Vol. 81, pp. 400-10.

Netemeyer, R.G., Brashear-Alejandro, T. and Boles, J.S. (2004). A cross-national model of job-related outcomes of work role and family role variables: a retail sales context. Journal of the Academy of Marketing Science, Vol. 32, No. 1, pp. 49-60.

Netemeyer, R.G., Maxham, J.G. and Pullig, C. (2003). Work-family conflict, job stress, and customer service performance, working paper. McIntire School of Commerce, The University of Virginia, Charlottesville, VA.

Ng, C.W., Fosh, P. and Naylor, D. (2002). Work-family conflict for employees in an East Asian airline: impact on career and relationship to gender. Economic and Industrial Democracy, Vol. 23, No. 1, pp. 67-105.

Parasuraman, S. and Greenhaus, J.H. (2002). Toward reducing some critical gaps in work-family research. Human Resource Management Review, Vol. 12, pp. 299-312.

Pleck, J.H. (1977). The work-family role system. Social Problems, Vol. 24, pp. 417-27.

Pleck, J.H., Staines, G.L. and Lang, L. (1980). Conflicts between work and family life. Monthly Labor Review, March, pp. 29-32.

Ursano, R.J., Grieger, T.A. and McCarroll, J.E. (1996). Prevention of posttraumatic stress: consultation, training, and early treatment, In Van der Kolk, B.A., McFarlane, A.C. and Weisaeth, L. (Eds), Traumatic Stress: The Effects of Overwhelming Experience on Mind, Body, and Society. Guildford Press, New York, pp. 441-62.

Whitely, W. and England, G.W. (1977). Managerial values as a reflection of culture and the process of industrialization. Academy of Management Journal, Vol. 20, pp. 439-53.

Yavas Ugur, Babakus, Karatepe M. Osman. (2008). Attitudinal and behavioral consequences of work -family conflict and family-work conflict does gender matter? International Journal of Service Industry Management, Vol. 19, No. 1, pp 7-31. 
Table 1. Descriptive Statistics

\begin{tabular}{|l|c|c|c|c|c|}
\hline & $\mathrm{N}$ & Minimum & Maximum & Mean & Std. Deviation \\
\hline Years in service & 40 & 1.00 & 4.00 & 2.95 & 1.08 \\
\hline Level of Education & 40 & 1.00 & 4.00 & 1.65 & .73 \\
\hline Age & 40 & 1.00 & 4.00 & 2.17 & .812 \\
\hline $\begin{array}{l}\text { Average daily working } \\
\text { hours }\end{array}$ & 40 & 6.00 & 10.00 & 7.90 & 1.39 \\
\hline No of Children & 38 & .00 & 2.00 & 1.07 & .74 \\
\hline $\begin{array}{l}\text { Source of House hold } \\
\text { support }\end{array}$ & 40 & 1.00 & 4.00 & 1.22 & .659 \\
\hline
\end{tabular}

\section{Year in Service:}

$1=$ less than 1 year, $2=$ more than 1 but less than 5 years, $3=$ more than 5 but less than 10 and $4=$ more than 10 years

\section{Level of education}

$1=$ Graduate (more than 12 years schooling, $2=$ Masters $3=\mathrm{PhD}, 4=$ Others

$\underline{\text { Age }}$

$1=$ within $30,2=$ more than 30 but less than $40,3=$ more than 40 but less than 50 and $4=$ more than 50 years

Source of house hold support

$1=$ Maids, $2=$ Parents in law, $3=$ Own parents $4=$ Others

Table 2. Children and WFC (Children are affected because of WFC)

\begin{tabular}{|l|c|c|}
\hline & Frequency & Percent \\
\hline Neutral & 8 & 20.0 \\
\hline Agree & 12 & 30.0 \\
\hline Strongly agree & 20 & 50.0 \\
\hline Total & 40 & 100.0 \\
\hline
\end{tabular}

\section{Work hour affect WFC}

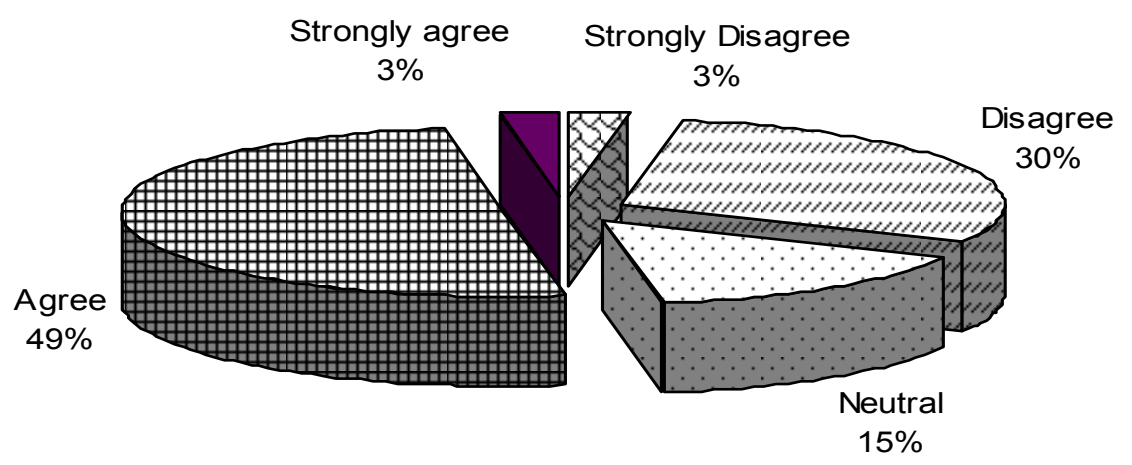

Figure 1. Working hours positively associated with work -family conflict (Respondent answer in percentage) 


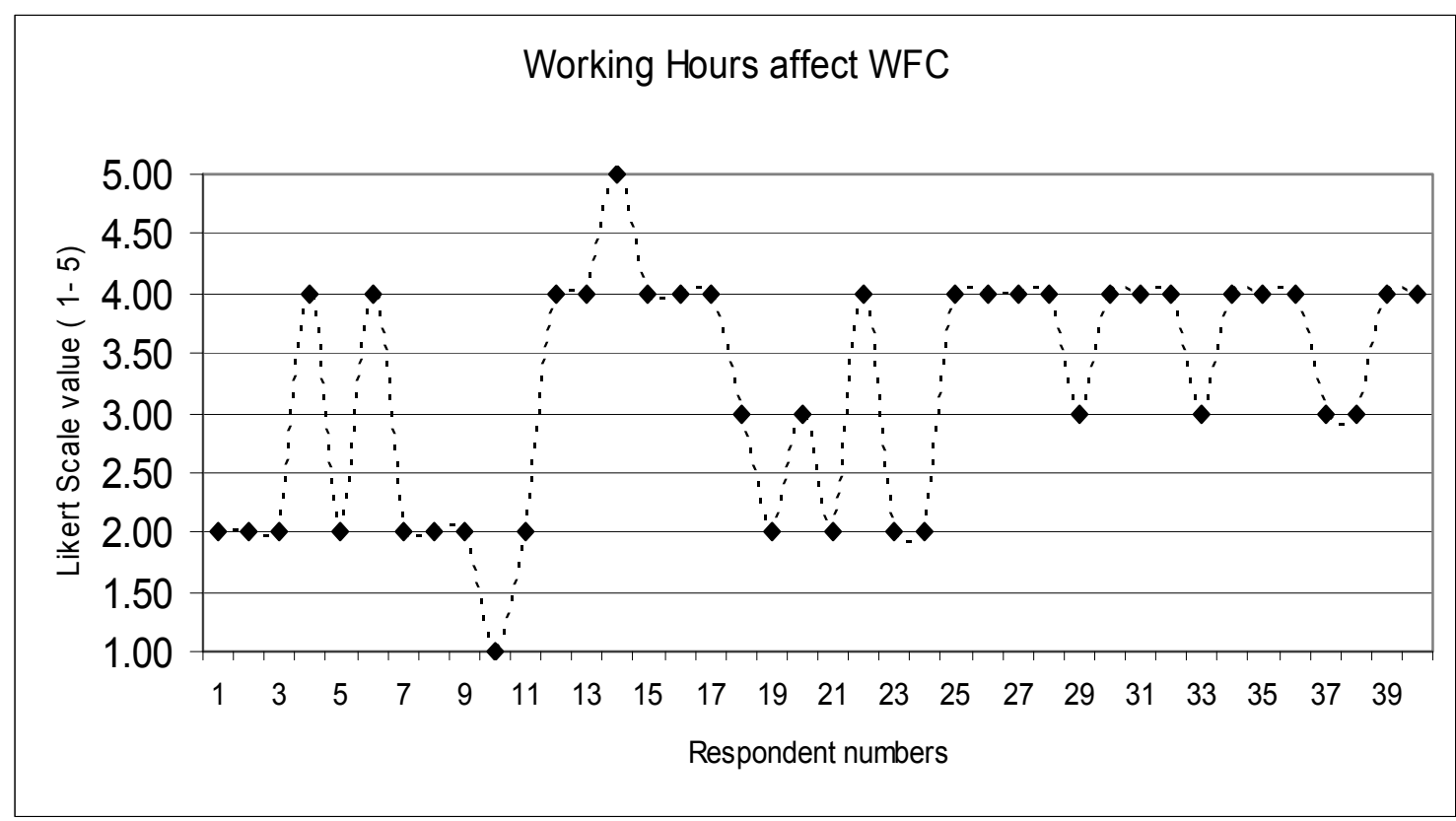

Figure 2. Individual respondent answer "Working hour affect WFC"

$1=$ Strongly disagree, 2 = disagree, $3=$ neutral, $4=$ agree, $5=$ strongly agree

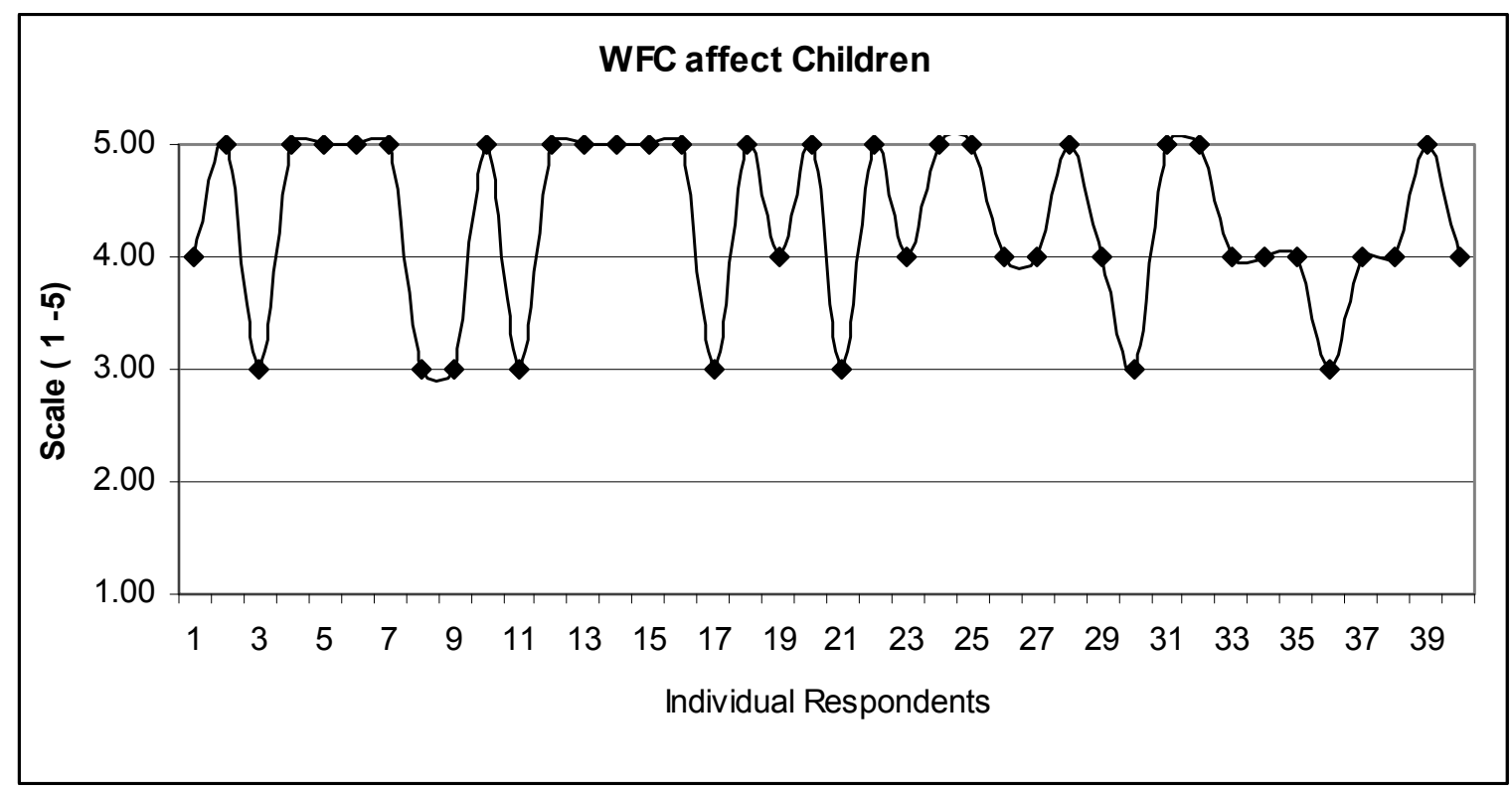

Figure 3. Individual respondent answer "WFC affect Children"

$1=$ Strongly disagree, 2 = disagree, $3=$ neutral, $4=$ agree, $5=$ strongly agree 